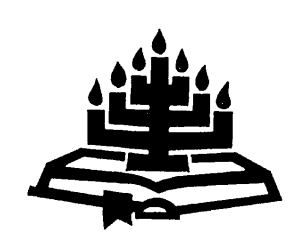

\title{
The foundational statement in Matthew 5:17-20 on the continuing validity of the law ${ }^{1}$
}

\author{
F.P. Viljoen \\ Unit for Reformed Theology \\ Potchefstroom Campus \\ North-West University \\ POTCHEFSTROOM \\ E-mail: viljoen.francois@nwu.ac.za
}

\section{Abstract \\ The foundational statement in Matthew 5:17-20 on the continuing validity of the law}

The statement of Jesus in Matthew 5:17-20 forms a pivotal point of Matthew's teaching on the law. Yet, some scholars argue that these verses reveal a strong Jewish character, with eclectic layers of traditions that even contradict one another. Matthew is being accused of careless inclusion of this material into his text which led to an inconsistent overall teaching of the law. This article proposes that a careful reading of the different elements of the statement within its context reveals its coherence. The statement forms an inherent part of the Sermon on the Mount and the rest of the Gospel through which Matthew in a pastoral manner addresses concerns of his community regarding their righteousness.

1 I am greatly privileged to contribute to this Festchrift in honour of Prof. Tjaart van der Walt. His many years of teaching the New Testament have inspired many of his students and are reflected in a number of popular scientific publications from his pen. His ability to unearth the rich message and nuances of the biblical text in a crystal clear and personal manner, led to the fact that his teaching and publications enjoy a privileged status among reformed students and scholars. 


\title{
Opsomming
}

\section{Die fundamentele stelling in Matteus 5:17-20 oor die volgehoue geldigheid van die wet}

\begin{abstract}
Jesus se stelling in Matteus 5:17-20 vorm 'n sleutelpunt in Matteus se leer oor die wet. Sommige navorsers meen egter dat hierdie verse 'n sterk Joodse karakter openbaar, met eklektiese lae van tradisies wat mekaar selfs weerspreek. Matteus word daarvan beskuldig dat hy op 'n argelose manier materiaal in sy teks ingevoeg het wat oorkoepelend tot 'n onsamehangende leer oor die wet lei. Hierdie artikel beredeneer dat, indien die verskillende elemente van die stelling versigtig binne konteks gelees word, die samehang wel duidelik is. Die stelling vorm 'n inherente deel van die Bergrede en die res van die Evangelie waarin Matteus op 'n pastorale manier die kommer van sy gemeenskap oor geregtigheid hanteer.
\end{abstract}

\section{Introduction}

Matthew 5:17-20 is pivotal to Matthew's teaching of the law, not only in the Sermon on the Mount, but within the whole framework of his Gospel. This passage is densely formulated, forms the first statement of Jesus concerning the law, and precedes all the Streitgespräche (debate) and legal material in the Gospel.

Very few passages in the New Testament have enticed so much scholarly debate as the interpretation of these verses. Part of the problem is that this highly concentrated statement is made up of a series of mashal-sayings that speak in an unexpected, paradoxical and absolute manner (Van der Walt, 2006:172). Each of these proverbial sayings "accentuates a particular side of the truth without considering the possible exceptions to the rule ... the hearer then has to ponder the matter himself" (Ridderbos, 1987:112). To add qualifications to these sayings would have caused the words to loose their impact (Morris, 1992:91).

It has been argued that Matthew 5:17-20 portrays an understanding of the law with a strong Jewish character, which do not cohere with Matthew's overall teaching. Some scholars are of the opinion that Matthew (by including these words) did not think through the whole problem of the law and that he was eclectic and even sloppy in his treatment of the issue (Descamps, 1995:173; Luz, 2005:186). In this passage Matthew even intensified the demands of the law as Torahverschärfung, based on his immediate awareness of the will of God (Kümmel, 1934:121-127). But then it seems as if Matthew contradicts himself by his description of the teaching and life of Jesus 
that follows. With the arrival of form-critical methodology, this problem was easily solved by relegating Matthew 5:17-20 as (a) piece(s) of text coming from a conservative Jewish-Christian milieu, which does not concur with the rest of Matthew's report on the life and teaching of Jesus. This would confirm the form-critical idea of cracks in the text. Since the advent of the redaction-critical analysis, however, more emphasis has been placed on the role of the evangelist in reworking the tradition to form a logical flow of argument (Banks, 1974b:226).

In this article, I argue that the author of the first Gospel presents Jesus' foundational statement about the continuing validity of the Torah (Matt. 5:17-20) in a cohesive manner - in such a way as to address concerns about the continuing validity of the law. In doing this, I will attend to the literary context of the saying, its origin and redaction, and then follow with the interpretation of the respective verses of the statement. From this investigation conclusions will be drawn.

Before entering into this discussion, I deem it necessary to draw the reader's attention to my presuppositions, as they do influence this study. Without entering into the debate of the historical person who wrote this Gospel, I use the name Matthew for the final redactor of the Gospel, as well as the written Gospel that stands first in the New Testament canon. I regard the Matthean community as a fairly large group or cluster of communities who shared specific religious concerns about their belief in Jesus (Ascough, 2011:102; Keener, 1999:45; Saldarini, 1994:98). The author of the Gospel knew of their struggles and tailored his message in such a way to address their concerns. An understanding of the social setting of the community helps to recognise the subtle emphases and allusions in the text (Luz, 1990:79; Viljoen, 2007:262). I regard the social setting of this Gospel within the troublesome relationship with parties in formative Judaism (Overman, 1990:8; Stanton, 1992:124). The community apparently was ostracised for their understanding and practice of the law (Viljoen, 2006:140). The Gospel is read as a transparent story in which Matthew reports Jesus' statements on the continuing validity of the law in such a way that the struggle of the Matthean community on the meaning of the law can also be recognised (Viljoen, 2009:651).

\section{The literary context of the foundational statement}

The foundational statement on the law (Matt. 5:17-20) forms a pivotal part of Matthew's prominent theme about the meaning of the 
law in relation to the teaching and life of Jesus. This statement is situated within the Sermon on the Mount, the first of five great discourses in the Gospel: the Sermon on the Mount (Matt. 5:1-7:27), the missionary charge (Matt. 10:5-42), the parables-discourse (Matt. 13:3-52), instructions to the community (Matt. 18:3-35), and the eschatological discourse (Matt. 24:4-25:46). These five discourses serve as main building blocks or architectonical structure of the first Gospel. Some scholars have seen in this structure an allusion to the five books of the Pentateuch (cf. Bacon, 1930:48), an idea that fits into Matthew's overall emphasis on the law, yet not all scholars agree.

In the Sermon on the Mount, Matthew presents Jesus' teaching on the law in a rather lengthy discourse. Many scholars do not regard this as one sermon delivered by the historical Jesus during one occasion. One suggestion is that Matthew gathered and adapted sayings of Jesus that He uttered during several occasions (cf. Domeris, 1990:67). Johnson (1951:240) remarks:

Jesus would not have given all this teaching on a single occasion. The sermon is made op of aphorisms, maxims and illustrations which were remembered and treasured out of many discourses.

Obviously the sermon in the Gospel can not be a verbatim report, as much of the material is found scattered in varied forms in other contexts in Luke's Gospel (Van der Walt, 2006:173). It is possible that some of the material found in the sermons was delivered in varied forms on another (and more than one) occasion. Morris (1992:92) remarks: "An itinerant preacher normally makes repeated use of his material, often with minor or even major changes." It is obvious that Matthew has made use of inherited material, which he edited to fit into his overall argument and offers it as an address of Jesus. He offers this text as a sermon of Jesus as, in the introductory (Matt. 5:1-2) and the concluding verses (Matt. 7:28-29), Matthew refers to the beginning and end of Jesus' address.

In this discourse, Matthew alludes to Moses when presenting Jesus. Some scholars even refer to Jesus as being presented as the new Moses (cf. Allison, 1993:137-270; Floor, 1969:34). Already at the beginning of the Sermon where Jesus went up the mountain to teach (Matt 5:1-2), the Sinai typology is significant (Loader, 1997:165). This opening leads to an anticipation of a new revelation to be delivered by a new Lawgiver. This expectation is met where Jesus repeatedly refers to the meaning and intention of the law and 
elaborates on the decalogue as such. In Judaism it was a wellknown concept that the Mosaic character could transmigrate to later legislators and teachers (e.g. Ezekiel). According to 4 Ezra the scribe received the old revelation of Sinai plus additional, new revelations (Allison, 1993:185). Within this convention, Jesus is portrayed as teacher and revealer comparable to Moses. His authority is emphasised, as Matthew concludes the Sermon with a postscript: "the crowds were amazed at his teaching, because He taught as one who had authority, and not as their teachers of the law" (Matt. 7:28-29).

Some scholars find a polarisation between the Sermon on the Mount and the rest of the Matthean Gospel. It is assumed that the broader Matthean kerugma of the saving death and resurrection of Christ has been replaced by the doctrine of reward in the Sermon on the Mount. Betz (1985:17 ff.) suggests that the Sermon on the Mount is an epitome of the teaching of Jesus, as compiled by Jewish Christians in Jerusalem around the middle of the first century. For them, Jesus was only an authoritative teacher of the law. The saving death of Jesus was not part of their religion. Matthew has incorporated their work despite the fact that it differs significantly from his own viewpoint. However, the view that the Sermon on the Mount is lacking a Christology, beyond Jesus as the respected teacher of the law, is rejected by most scholars (cf. France, 1998:163). ${ }^{2}$ The Sermon on the Mount should not be viewed only as a general discourse on ethics, but actually as the description of the distinctive life of those who are under the rule of the kingdom of heaven. As throughout Matthew's Gospel, it is those who respond to Jesus who come under the rule of God. It is for his sake that they are persecuted (Matt. 5:11). The Sermon on the Mount therefore fits into the development of Matthew's plot, the revelation of Jesus as the Messiah, and peoples' response to his message.

The Sermon on the Mount begins with a set of statements, which describe the way of life of faithful disciples of Jesus. "As a musical masterpiece begins with an introitus, the Sermon on the Mount opens with an extraordinary sequence of statements, the so-called beatitudes" (Betz, 1995:92). Taken together, the set of beatitudes in

2 The Reformers and Puritans used to summarise the relation between Jesus (as Christ) and the law. The law sends us to Christ to be justified, and Christ sends us back to the law to be sanctified (cf. Stott, 1978:36). Lloyd-Jones (1976:18) wrote: "There is nothing that so leads to the gospel and its grace as the Sermon on the Mount." 
Matthew $5: 3-12^{3}$ constitutes the exordium of the Sermon on the Mount. The beatitudes are pastorally-orientated promises, which Matthew employs to encourage his community, even when being ostracised because of their discipleship and way of living: "Blessed are you when people insult you, persecute you and falsely say all kinds of evil against you because of me ..." (Matt. 5:11-12). While the Sermon begins with a series of blessings (Matt. 5:1-12) it ends with a series of warnings (Matt. 7:1, 15, 21 \& 26-27). This pattern is similar to the Book of the Law (Deuteronomy), which suggests a parallel between Jesus and Moses, both as mediators of the commandments of God (Domeris, 1990:67).

The statement in Matthew 5:17-20 is preceded by a section of exhortations. The parallel metaphors of salt for the earth (Matt. 5:13) and light for the world (Matt. 5:14-16) depict the appropriate actions that should be significant in the life of Jesus' disciples. Some scholars find a definite break between verses 16 and 17 (e.g. Meier, 1976:42). However, the break is not that abrupt. Members of Matthew's community probably tended to remove themselves from society because they were persecuted for their understanding and practise of righteousness. Matthew exhorts them not to retract, but to continue witnessing with their style of living, as they were indeed following the right teachings. With the statements that follow, Matthew confirms that they are indeed adhering to the law as taught by Jesus, their foundational leader. He presents the model for this distinctive discipleship in Matthew 5:13-16, and then continues to address the basic criticism of the opponents, who regard the life of discipleship required by the Matthean community, as an abrogation of the Torah. Matthew uses these exhortations in a pastoral manner to encourage his community to continue with their way of living, even when experiencing persecution. The community should not keep silent or hide from the world (Foster, 2004:164).

3 The set of beatitudes with which Matthew begins the Sermon on the Mount, differs quite significantly from those recorded by Luke. Luke only gives four beatitudes and balances them with four woe sayings. The Matthean beatitudes probably form a collection of sayings by Jesus (not necessarily as the ipsissima verba Jesu). Jesus might have pronounced blessings combined with curses as found in Old Testament parallels (Gen. 27:27-29, 39-40; Deut. 28). In an attempt to explain the difference between the Matthean and Lukan versions of the beatitudes, Van Bruggen (1990:85) makes the unconvincing suggestion that "[b]eide evangelisten hebben echter uit de stellig langere bergrede hun eigen keuze gemaakt", as now evidence is available of such and extended list. 
The foundational statement on the law is concluded in Matthew $5: 20$. Structurally and thematically this verse forms a link between the previous statement and the halakhic argumentation with six antitheses that follow. The structural link is visible as the formulaic opening words $\lambda \dot{\varepsilon}^{\prime} \gamma \omega$ jò $\rho \dot{v} \mu \hat{\imath} v$ are repeated in each of the six antitheses that follow (Matt. 5:22, 28, 32, 34, 39, \& 44). Thema-

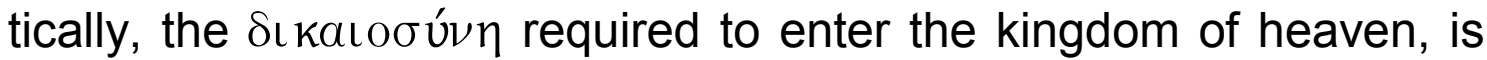
illustrated by the following set of antitheses. Allison (1993:183) remarks: "Structurally, 5:21-48 consists of six paragraphs, each illustrating the truth of 5:17-20." Furthermore the use of the term

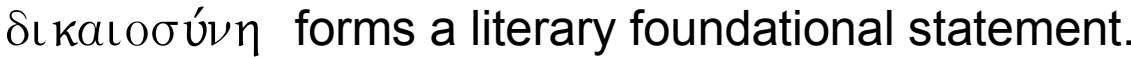

This investigation into the literary context of Matthew 5:17-20 shows that the foundational statement on the law does fit into the overall structure of the Sermon on the Mount. In turn, the Sermon on the Mount has a functional position within the architectonical structure of the Gospel with its emphasis on the meaning of the Torah. The statement can therefore not be correctly understood in isolation of the wider narrative.

\section{Origin and redaction of Matthew 5:17-20}

The study of Matthew 5:17-20 is complicated by the complex and debated tradition history of the verses. According to some scholars, each of the verses has to be assigned to different strata of the early community, as they present differing views of the law (Moo, 1984: 24). In dealing with the saying that appears to promote strict observance of the Torah, scholars have suggested that Matthew took over pre-Matthean material that does not smoothly fit into his overall argument (Luz, 2005:6). Streeter (1924:512) suggests:

This tradition, corresponding to that element in Matthew which we have styled $M$, includes sayings of a strongly Judaistic character .... It can not be too emphatically insisted that this element in Matthew reflects, not primitive Jewish Christianity, but a later Judaistic reaction against the Petro-Pauline liberalism in the matter of the Gentile Mission and the observance of the Law.

Brooks attempted to identify $M$ material and suggested that contradictions or paradoxes in the text (aporiae) may reveal source material. He speaks of "a disjunction in the text that would not be expected from an author" (Brooks, 1987:18). Following the same argument, scholars have suggested that the content of Matthew 5:17-20 do not cohere with the evangelist's overall theology, and 
should therefore be regarded as a clumsy use of inherited material by the author. Many interpreters "dislike the thought of attributing such a legalistic logion to the evangelist" (Luz, 1990:258). With regard to Matthew 5:19, Meier (1976:165) remarks: "In many ways, $5: 19$ is the most difficult verse to explain within the present Matthean context. It seems like an undigested morsel next to the carefully redacted 5:18." He (Meier, 1976:165) further suggests that

5:18-19 in the tradition may show successive stages of JewishChristian attitudes on the Law. Vs. 5:18bc may reflect the severe view of stringent Jewish Christians, while 5:19 may be the corrective of more moderate Jewish Christians. This attempt at moderation has produced a curious piece ..., a kind of literary fossil now embedded in 5:19.

Related to this, the question arose which of this material can be traced back to the historical Jesus, and to make Him the anchor of interpretation of the law. Guelich (1982:152) remarks:

Whereas 5:17, 18 may have distant roots in Jesus' ministry, $5: 19$ reflects the nomistic nuance of a strict Jewish-Christian community who may well have shaped the tradition of 5:17, 18 and added 5:19 as a commentary.

In discussing the redaction of Matthew 5:17-19, Foster (2004:178) argues that "it seems foolhardy to assert that these Matthean verses find their origin in the ministry and teaching of Jesus in anything more than the faintest of echoes".

It is very likely that more persons, other than the four Evangelists and the author of the assumed Q, wrote about the life of Jesus. Besides the "Two Document" and "Four Document" theories it is very difficult to decide how the evangelists made use of existing material. Many scholars spend a lot of effort trying to identify the sources of Matthew and what he has done with them. In fact, none of the other material has survived. As discussed in the previous section on the literary context of Matthew 5:17-20, it rather seems that when Matthew incorporated a source, it was because he made it his own and appropriated it to fit into his discourse. It is therefore more important to understand what the words mean in their new situation. Childs (1984:62) aptly remarks on this.

The assumption that the many tensions within the Gospel are to be resolved by sharply distinguishing between tradition and redaction ... renders impossible a canonical reading of the Gospel as a whole. Thus the judgment that portions of ch. 5 are 
'traditional ballasts' which distort Matthew's real intention, is a highly tendentious approach.

In the following interpretation of Matthew 5:17-20, it will be argued that this foundational statement does fit into the argument of Matthew. Obviously he made use of sources, but he has used them in such a way that they fit into his understanding of the validity of the law in his context. He explicitly anchors his perspective of the law on the authoritative teaching of Jesus.

\section{Interpretation in context}

\subsection{Matthew 5:17}

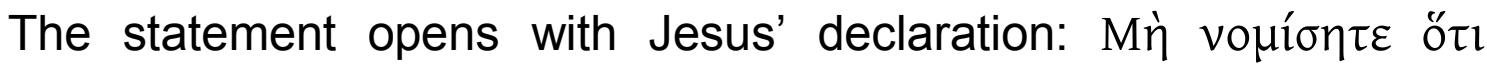

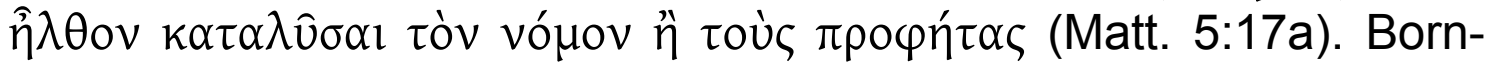
kamm (1963:51) and Barth (1963:160) proposed that these words are addressed at two apposing fronts: on the one side the Jews who do not believe in Jesus, and on the other side antinomians within Matthew's community. It is clear that Matthew (with these words) anticipates charges against his community's understanding of the law. Davies and Allison (2004:481) describe these verses as a prokatalepsis in anticipation of possible objections. The purpose of $\mu \eta \dot{~ v o \mu i ́ \sigma \eta \tau \varepsilon ~ i s ~ " t o ~ c o u n t e r ~ f a l s e ~ a s s u m p t i o n s ~ o r ~ m i s u n d e r s t a n d i n g s ~}$ about Jesus' coming" (Guelich, 1982:136). However, Matthew's addressees consist of his own community, rather than of the outsiders who do not believe in Jesus, or antinomians. (Matthew's) Jesus begins with the second person plural in Matthew 5:11 and carries it through Matthew 5:13, and repeats it in Matthew 5:17 and Matthew 5:20, and keeps the pattern in the antitheses. In Matthew's mind, these words are not directly a defence against Pharisees and teachers of the Law, but an explanation of the meaning of the law to his community (Meier, 1976:66). Indirectly, Matthew addresses the opponents who brought these charges, but his main concern is his own community, as they were being ostracised for their way of living (Luz, 1990:260).

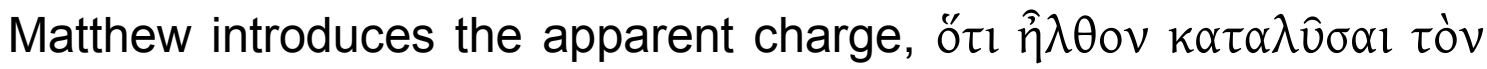

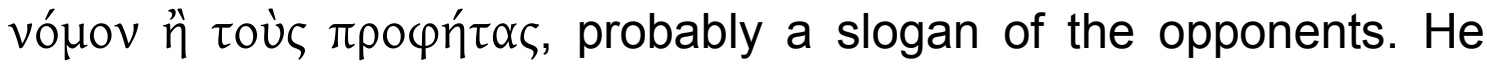
immediately refutes the charge with a pastoral encouragement to his unsettled community, who must have been accused and persecuted by Torah observant opponents (Foster, 2004:212). At this point, it becomes important to decide on the meaning of the word vópos. Taking into account that the word is used in conjunction with 
$\pi \rho \circ \varphi \eta \dot{\tau} \alpha \iota$ and with the parallel of $i \omega \hat{\tau} \alpha$ and $\kappa \varepsilon \rho \alpha i ́ \alpha$ in the next verse, it most likely refers to the written law, and not the oral traditions which Pharisees also regarded as being part of the Torah. The presence of the term $\hat{\eta} \lambda \theta 0 v$, has lead some scholars to argue that this saying belongs to logia and Reflexionszitate known as $\hat{\eta} \lambda \theta 0 v-$ words. Von Harnack (1912:1-30) has identified a Gattung in the synoptic tradition with "die ausdrücklichen Selbstzeugnisse Jesu über den Zweck seiner Sendung und seines Kommes". With the "I have come"-statements, Jesus was conscious of his divine mission as redeemer and law-giver. Jesus denies that $\mathrm{He}$ has come to $\kappa \alpha \tau \alpha \lambda \hat{v} \sigma \alpha l$ the law and the prophets. Within this context, the verb means "to end the effect of validity of something" (Foster, 2004:184).

Very strategically Matthew uses this $\hat{\eta} \lambda \theta o v$-word to put the law and the prophets in context of the mission of Jesus. Matthew puts the law and the prophets, the centre of the Old Testament faith, in direct relation to Jesus, who is the centre of Christian faith (Meier, 1976:123). He affirms Jesus' loyalty to the Old Testament by proposing a prophetic reading and understanding of the law. Four of the eight occurrences of o $\nu$ ó $\mu$ o $\zeta$ in the Gospel are presented as part

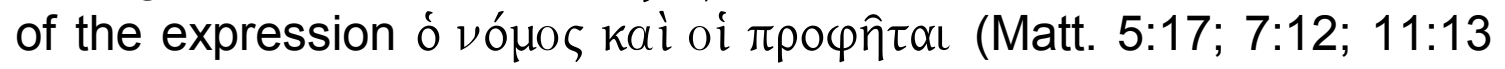
(in reverse order) \& 22:40). Two more are in the contexts where the law is being discussed in relation with the prophets 4 (Matt. 5:18 \& 22:36). Yet, another is referred to in context of the prophetic source where Hosea 6:6 is quoted to validate Jesus' comments (Matt. 12:5), and lastly an allusion to Micah 6:8 can be recognised in Matthew 23:23. Also, when the eating with unwashed hands becomes an issue (Matt. 15:1 ff.), a word from the prophets (Is. 29:13) provides an answer to the hypocritical objections of the opponents. Even the regulations about the temple activities (Matt. 21:13) are determined by words from the prophets (Is. 56:7 \& Jer. $7: 11)$. The implication is that the pharisaic application of the law is not in line with the prophetic view and it is therefore wrong (Matt. 23:28). In Judaism, the Torah was regarded as the direct expression of God's will. The prophets were the custodians and interpreters of the Torah ${ }^{\mathbf{5}}$ (Meier, 1976:72). Ultimately, Jesus Himself is presented as a prophet who gives the authoritative interpretation of the law. In his preaching and action Jesus stands in line with great Old-

4 Only the law and prophets were read during synagogue worship. Though the psalms were sung in worship, none of the writings were read (Meier, 1976:71).

5 The prophets were therefore regarded as less important than the Torah. 
Testament prophets who warned against religious hypocrisy and loveless formalism.

After repeating the negative accusation oủk $\hat{\eta} \lambda \theta o v k \alpha \tau \alpha \lambda \hat{v} \sigma \alpha 1$, to emphasise the contrast with what follows, the evangelist counterbalances the charge with a positive affirmation: $\dot{\alpha} \lambda \lambda \dot{\alpha} \pi \lambda \eta \rho \hat{\omega} \sigma \alpha l$ (Matt. 5:17b). The operative word is $\pi \lambda \eta \rho \hat{\omega} \sigma \alpha \mathrm{l}$. The dismissal of the accusation that Jesus came to $k \alpha \tau \alpha \lambda \hat{v} \sigma \alpha 1$ the law and the prophets, can only be appreciated when read parallel with $\pi \lambda \eta \rho \hat{\omega} \sigma \alpha l$ (Luz, 1990:260). It is important to notice that the word used as contrary to "abolish", is not to "confirm" or to "enforce" the law, but to "fulfil" it. The proper way to keep any commandment was to fulfil the purpose for which it was given. This implies that the interpretation of the law as done by Jesus, differs from what the opponents traditionally thought it to be. The debate therefore is not about the recognition or obedience of the law, but about the understanding of God's intention with the law (Hill, 1972:117). The fulfilment of the Old Testament in Jesus is the basic orientation of Matthew's Gospel (France, 1998: 196; Moule, 1967/1968:293-320), and thus also forms the crux of Jesus' argument on the law (Menken, 2003:181; Moo, 1984:24). "Fulfil" in this context has the meaning of bringing to full intent and expression. Jesus brings out the intended meaning of the law through his definite interpretation (Hagner, 1993:105). Jesus' own coming represents the fulfilment of the law (Ladd, 1993:123). Patte (1987:73) describes this fulfilment as the "vocation" of Jesus. He did not oppose the Torah, but brought it to fruition (Carson, 1982:77). Jesus came to affirm the Scriptures and to bring them to new actuality in people's lives. For Matthew, the law and the prophets continue to be authoritative - but as they are interpreted by Jesus (Stanton, 1993:49). The law finds its valid continuity in Jesus, the one towards whom it has pointed. With such an interpretation of Matthew 5:17 in mind, Banks (1974a:226) remarks:

It is not so much Jesus' stance towards the Law that he (Matthew) is concerned to depict: it is how the Law stand with regard to him, as the one who brings it to fulfilment and to whom all attention must now be directed.

\subsection{Matthew 5:18}

The opening words in Matthew 5:17 are followed by a statement that comprises of four separate clauses:

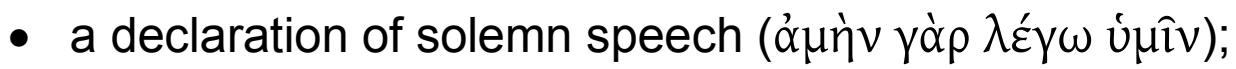


- a temporal statement concerning the ending of the created world

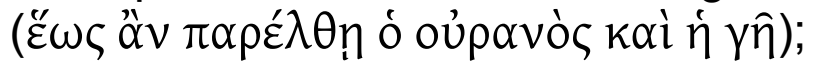

- a declaration of ensuring the validity of the smallest detail of the

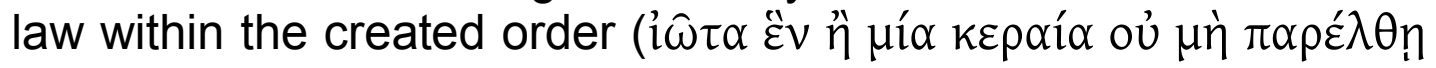

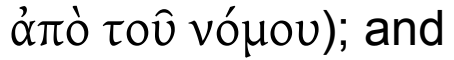

- a conditional qualification that reinforces the lasting validity of the

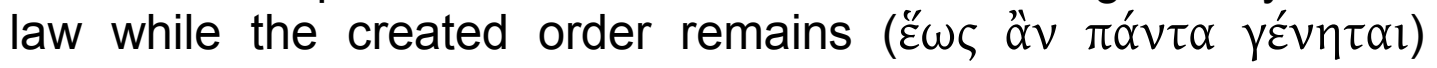
(Matt. 5:18). 6

The first clause "stresses the gravity of what follows" (Hagner, 1993:106). The solemnity is created by the use of the term $\alpha \mu \eta \dot{v} v$. The introductory position of this word is distinctively Christian, as it is not found in the Old Testament or rabbinic literature. Of the 51 times $\alpha \mu \eta \dot{v} v$ is used in the New Testament as a declaration of solemn speech, 31 of these instances are in Matthew (Foster, 2004:188). This is the first time Matthew uses the amen-formula, with the result that the impact would have been strongly felt by the first readers.

Having announced that a significant statement that deserves the full attention follows, the permanence of the law is secondly stated with a clause similar to various rabbinic passages where the same theme is developed (Banks, 1975:214). Matthew's Jesus uses a popular Jewish saying about the eternal validity of the law, and applies it to his teaching on the fulfilling of the law in order to demonstrate his essential continuity with it. Meier (1976:41-65), however, argues that this statement does not imply the continuing validity of the law, but is marking the terminus ad quem. He proposes a Heilsgeschichtescheme, where the death and resurrection of Jesus function as the turning of the ages, which would close the era of Torah obedience. This argument will be taken up again in the discussion of the fourth clause, which forms a parallelism to this second clause.

Thirdly, a declaration is made about the validity of even the smallest part of the law. The Semitic origin of Jesus' words is illustrated by the inclusion of Hebrew words $i \hat{\omega} \tau \alpha$ and kepaía in the text. Beyond providing some local colour to the narrative, it also demonstrates Jesus' respect for the Torah. Out of respect for the Torah only Hebrew was used in that period in discussions on the Jewish law (cf.

6 Most scholars recognise this fourfold division (cf. Davies \& Allison, 2004:487). 
Fitzmyer, 1970:501; Joosten, 2004:89). ${ }^{7}$ It might be that this logion somehow existed originally in Hebrew, and was probably been used to accuse the Matthew's community of wrong doing. The $i \hat{\omega} \tau \alpha$ was the smallest letter of the Hebrew alphabet. The idea of the $i \hat{\omega} \tau \alpha$ representing the the whole law, is reflected in a rabbinic story about Deuteronomy 17:17. According to this story, the Book of Deuteronomy complained before the Lord that Solomon had abolished a yot in it, and therefore in principle had abolished all of the book. The Lord replied: "Solomon and a thousand like him will pass, but not one word of you shall pass." (Strack \& Billerbeck, 1961:247.) The kepoía denotes the accents and breathings in the Hebrew text, thus referring to something seemingly insignificant. The meaning of the statement is qualified by the two clauses that precede and follow this saying (Banks, 1975:214). Obviously Matthew has in mind the objections of the opponents of the Matthean community, who questioned the way Jesus and the community observed the law. Matthew argues that fulfilling the law does not imply the punctilious observance of the Pharisees, but an observance as defined by Jesus. The authoritative teaching of Jesus reveals the whole meaning of the Torah (Hagner, 1993:106).

The fourth part of the statement should be read parallel to the second, as it reiterates the time until which the law will be valid. 8 Rabbinic sources witness to a variety of beliefs about the fate of the Torah in the messianic age to come (Davies, 1963:156-190): that it would stay the same; be inviolate forever; that obscure parts would become clear; that certain sacrifices and festivals would cease; that purity laws would be revised; or that a new Torah would come into place (Davies \& Allison, 2004:493). Scholars do not agree when that age will come. Some scholars argue that "until everything is accomplished" (Matt. 5:18), does not as such point to the end of the world, but to the fulfilment of all that God has planned. Therefore all is accomplished not so much by the faithful observance of the law, but rather in that its preparatory function has been successfully achieved. In this sense Meier (1976:65) proposes that the age had already arrived.

7 Kooyman (1992:79 ff.) argues that the distinction between Aramaic and Hebrew layers in the tradition cannot be distinguished that clearly. Beyond arguments around "die Muttersprache Jesu" one should not only distinguish Jesus' language in his ministry, but also the mother tongue of Matthew (the author). (Meier, 1976:53). 
The Mosaic Law as a whole and qua Mosaic lasts only until the apocalyptic event of the death-resurrection of Jesus. After this Wende der Zeit, the norm for the disciple is 'all whatsoever I commanded you'.

Referring to the events that took place with the death and resurrection of Jesus, Meier argues that the earthquake was a wellknown theophanic and apocalyptic motif from Jewish literature. He argues that Jesus' demands move in a sphere above the law, which continuing validity exists only in and through Him (Meier, 1976:88). Meier's thesis is opposed by Davies and Allison (2004:474), who argue that "until heaven and earth pass away" most naturally implies that there is still a period of time before the law passes away. While Sim (1999:125) agrees that the coming of the eschatological ages will bring and end to the Torah, he proposes that this event would take place with the parousia. A discussion on the apocalyptic timetable, however, is not really useful to understand Matthew's argument. The antitheses that follow do not in any way refer to eschatological events, but rather to Jesus' authority to teach the correct interpretation of the law for his disciples (Foster, 2004:211).

It is therefore more convincing that Matthew wants to assure his community that charges brought against them of not adhering to the Torah, are unfounded. In a pastoral manner, he affirms continuity with the law, but in a nuanced way as taught by Jesus. He claims that "the life of discipleship that he portrays as being taught by Jesus is not the abolition of the Law, but is in fact the consummative fulfilment of Torah values" (Foster, 2004:183).

Taking these considerations into account, Matthew's argument becomes clear. He argues that Jesus expressed the full intended meaning of the law. In this regard, France (1998:196) suggests that one should distinguish between the authority and the function of the Old Testament law. To affirm that the law remains authoritative with no jot or tittle lost, does not necessarily imply that it will continue to function in the same way. When read along with the focus on the fulfilment as the key to understanding Jesus' relation to the law, it is obvious that the practical functioning of the law would not remain the same as it was before his coming. Even though the law remains permanently important, it should function differently in a pre- and postfulfilment situation. He completed the law by extending its demands and bringing it to which it pointed. Jesus' teaching and ministry would demonstrate this fulfilment. Matthew is therefore saying to his adversaries, the law is fulfilled, but not in the manner you 
expected it (Foster, 2004:186). The antitheses that follow in Matthew $5: 21-47$, demonstrate this interpretation of the meaning of the law.

\subsection{Matthew 5:19}

The foundational statement on the validity of the law continues with a parallel result of either "loosing and teaching" or "doing and teaching" the commandments or ordinances of the Torah:

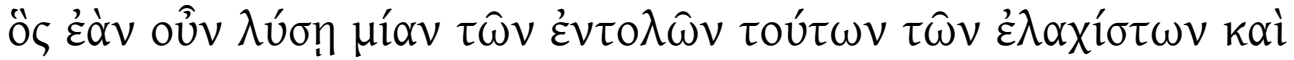

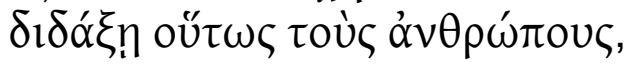

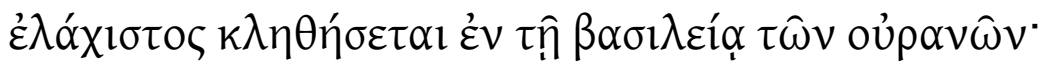

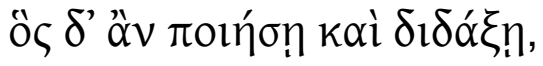

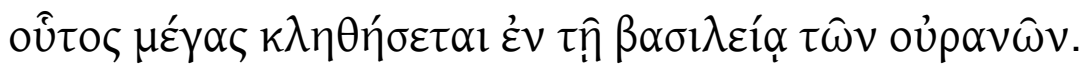

The form as well as the content of this parallelism is that of a legal statement. Käsemann (1969:19) defines the form as Sätze heiligen Rechtes. The protasis and apodosis correspond in the relationship of guilt and punishment (Matt. 5:19ab), or fulfilment of duty and reward (Matt. 5:19cd).

The question arises whether action of annulling $\lambda u ́ \omega$ (Matt. 5:19a) implies teaching or doing. As the word stands parallel to $\pi 01 \varepsilon \omega$ (Matt. 5:19c), the idea of breaking by action is better suited in this context (Meier, 1976:90). The object of annulment is called $\mu i \alpha v \tau \hat{\omega} v$

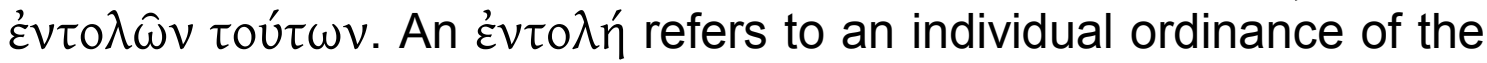
law as a whole. This statement probably refers to the pharisaic debate on the scale of importance of the counted 613 miswot in the Torah (Strack \& Billerbeck, 1961:90). 9 With reference to the implied ranking of miswot in this verse, Sim (1999:126) argues that Matthew was a Christian Jew who believed that even the least of the Mosaic commandments had to be observed and taught to others. Countering this proposal, scholars such as Lohmeyer (1967:110) and Banks

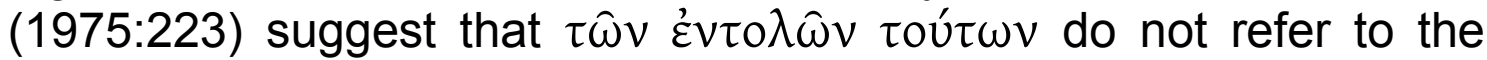
ordinances of the Torah, but to Jesus' own commandments. Their argument is not convincing as this statement forms part of a cluster of sayings dealing with the validity of the "law and the prophets" by

9 According to the popular view one never knew what reward to expect for obeying which precept. As a result a light precept should be esteemed as a heavy one and all should be regarded as of equal importance (Strack \& Billerbeck, 1961:90). 
which the author responds to accusations of breaking the law. France (1998:195) responds to Bank's proposal remarking that his proposal "is to destroy the clear sequence of thought from verse 18 to verse 19, and to ignore the regular use of $\dot{\varepsilon} v \tau 0 \lambda \eta$ to refer to Old Testament laws". It is clear that Matthew still refers to the $i \hat{\omega} \tau \alpha \tilde{\varepsilon} v \grave{\eta}$

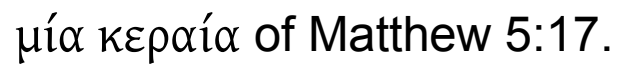

The combination between doing and teaching in Matthew 5:19 is significant. The older rabbinic view had been that the practical observance of the law was more important than the study of it. Only after Hadrian's edict that forbade the study of the Torah, did rabbis under Akiba decide that the study of the law is more important - as study led to practice (Strack \& Billerbeck, 1961:84). The difference between $\pi 01 \varepsilon ́ \omega$ (Matt. 5:19) and $\pi \lambda \eta \rho o ́ \omega$ (Matt. 5:17) is noteworthy. Lohmeyer (1967:111) explains the difference between Jesus who fulfils the law to its full meaning (Matt. 5:17), and the disciples who are subjects of the law and who obey them.

Considering the punishment and reward side of this legal statement, it is interesting to note that the exclusion from the kingdom is not envisaged as a result of not observing of the least of the commandments, but a ranking of persons. This is related to rewards as motivation for the correct conduct (Hagner, 1993:109). The idea of gradations of honour and dishonour in the kingdom of heaven was common in rabbinic tradition. Rabbis noted that one could not be certain in this world who is great and who is small. That would become clear in the world to come. Those who were prepared to make themselves small for the sake of the Torah would become great in the future world. Once one's status in the next world has been attained, it could not be changed (Strack \& Billerbeck, 1961:

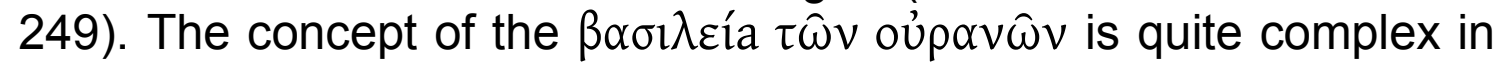
Matthew. The past, present and future are all involved in various stages of the coming of the kingdom. In Matthew 5:19 the future reference is most probable, read in context of the reward and punishment scheme of the rabbis, and because of the close proximity of the same word in Matthew 5:20 where it clearly has a future meaning.

\subsection{Matthew 5:20}

In a Janus-like hinge, Matthew 5:20 serves as conclusion to the preceding statement of the validity of the law and as link to the antitheses that follow. It starts of with the introductory formula, thereby making this statement an emphatic summary of the previous 
statements and of the antitheses that follow. Then, as in the previous verse, follows a statement with the basic form of a Satz heiligen Rechtes which consists of a protasis and an apodosis:

Introductory formula:

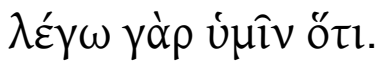

Satz heiligen Rechtes:

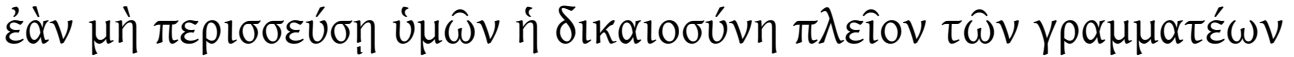

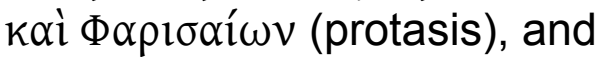

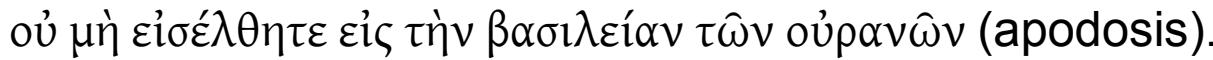

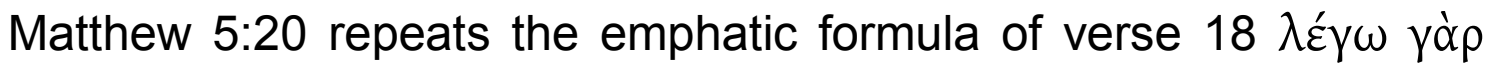
v $\mu \hat{\imath} v$, hinting to the independent, authoritative teaching of Jesus. This verse once again responds to the implied accusation in

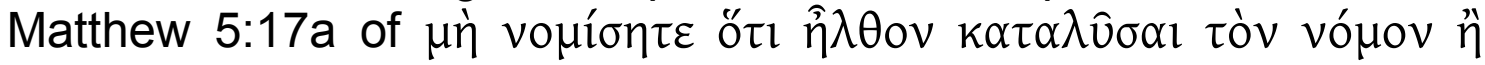

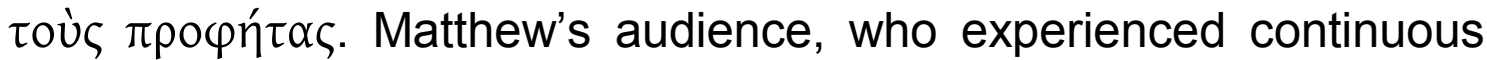
accusations regarding their understanding and practice of the law, could find themselves in this story (Carter, 1994:32; Overman, 1996:80).

Occording to the Satz heiligen Rechtes, Matthew's Jesus wants his disciples, and Matthew wants his community to surpass their opponents in righteousness. The popular rabbinic view was that one had to fulfil the legal prescriptions of the law punctiliously to gain merit. It was important to gain enough merit to outweigh one's guilt at the final judgement (Meier, 1976:109). The question arises whether Matthew likewise required the $\delta i k \alpha l o \sigma u ́ v \eta$ of his community to surpass that of the opponents in quantity or rather in quality. Though some scholars such as Segal (1991:21) regard the surpassing as quantitative, it should rather be interpreted as qualitative. Matthew does not require a bigger and better pharisaism, or a more punctilious observance of the minute parts of the law. The "more abundant" is explained by the six antitheses that follow in Matthew 5:2148 and the charge of hypocrisy in Matthew 6:1-6. The wrong conduct of the scribes and the Pharisees is not the result of the quantity of their deeds, but because of their wrong understanding of the law and of a false attitude behind their deeds. The opponents are denounced for parading their pious acts in public to gain praise, while members of Matthew's community is encouraged to perform their acts of piety in private where only God can see (Sim, 1999:122). 
Matthew's use of $\delta 1 k \alpha 10 \sigma u ́ v \eta$ must be distinguished from that of

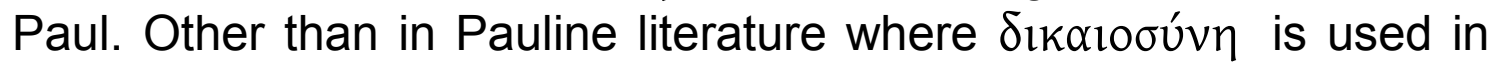
forensic terms, Matthew mostly uses the term in an ethical sense. Przybylski (1980:13 ff.) argues that in Matthew tsedeq rather than tsedaqah forms the meaning of $\delta 1 k \alpha 10 \sigma u ́ v \eta$. While tsedaqah denotes soteriology as gift from God, tsedeq is the norm according to which a person's behaviour is measured before God. It refers to the conduct of a person in accordance with the will of God. In Matthew $5: 20$, Matthew uses $\delta 1 k \alpha 10 \sigma u ́ v \eta$ in terms of teaching and doing the will of God. This phrase gives expression to Matthew's understanding of true discipleship. Matthew assures his addressees that the righteousness is the outcome of living according to the interpretation of the law, as taught by Jesus. According to Matthew 5:10, community members were persecuted because of their "righteousness", but were comforted with the promise of sharing in the kingdom of heaven (Matt. 5:10b). Similarly in Matthew 5:20 the readers are urged to practice greater righteousness than that of the teachers of the law and the Pharisees, so that they can enter the kingdom of heaven.

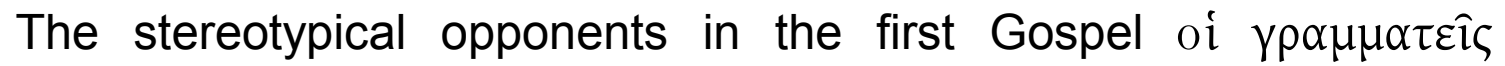

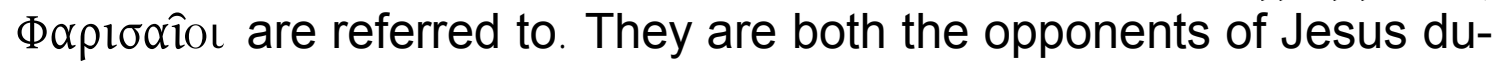
ring his ministry, and of the Matthean community. The scribes in particular were the interpreters and teachers of the law, and devoted themselves to studying and teaching it. The Pharisees were a group of pious Jews who devoted themselves to strict observance of the law, both oral and written. They were one of the Jewish religious groups and often included teachers of the law. They were especially known for their zeal to keep the law (Meier, 1976:112). Guelich (1982:159) distinguishes between the scribes as teachers of the law, and Pharisees as the doers of the law. However, Matthew does not sharply distinguish between these two groups. To Matthew both groups represent Jewish theology and piety, and act as continuous opponents of Jesus.

In the apodosis of the Satz heiligen Rechtes Matthew discusses the reward or punishment in terms of entering the kingdom of heaven. Meier (1976:113) suggests that two images lie behind Matthew's use of the expression "to enter the kingdom of heaven", i.e. the entrance of Israel into the promised land (Deut. 4:1), and the requirements of cultic purity and ethical righteousness to enter through the temple gates (Ps. 15, 24 \& 118:19). In Matthew 5:20 this image is projected onto eschatological events. These final words of the pericope tie up with the last words of Matthew 5:3,10,19b and 19d 
- thus providing a unity to the first part of Matthew 5 . The expression is only taken up again at the end of the Sermon in Matthew 7:21 to conclude the extended argument.

\section{Conclusions}

With the fundamental statement of the law in Matthew 5:17-20, Matthew made use of inherited materials. However, to argue that the statement is an eclectic and careless compilation of clashing elements and that the statement as a whole does not smoothly fit into Matthew's overall teaching of the law, is unfounded. Rather, he had a clear message and presented it consistently.

The study of the different parts of this statement proved that Matthew carefully composed this statement. The interrelatedness of the different components is significant. It starts off by denouncing false assumptions about Jesus and the law. In Matthew 5:17 he uses $\hat{\eta} \lambda \theta$ ov - sayings that are in parallel to describe how Jesus brought and taught the intended meaning of the law. This is followed in verse 18 , with a carefully structured four part solemn declaration about Jesus' respect for even the seemingly insignificant parts of the law. Verse 19 presents a double Satz heiligen Rechtes to affirm the results of "loosing and teaching" or "doing and teaching" the commandments or ordinances of the Torah. The statement concludes with yet another solemn declaration with a Satz heiligen Rechtes, explaining the kind of righteousness required from disciples of Jesus. It is therefore imperative not to read the different parts in an atomistic manner with clashing layers of tradition, but in its redacted and cohesive form.

It is also necessary to recognise the place of this statement as a whole within the logical flow of discourse within the Sermon as a whole. The Sermon opens with a set of beatitudes describing true righteousness, the appropriate way of living by faithful disciples of Jesus (Matt. 5:1-12). This is followed by encouraging words to continue with such righteous living, even amidst intolerance and false accusations from opponents (Matt. 5:13-16). The accusation of breaking the law is then proved to be false by a solemn declaration of Jesus (Matt. 5:17-20). The final verse of this declaration functions as a Janus-like hinge to the following antitheses where Jesus' teaching of the precepts of the law is presented.

This densely formulated statement of Jesus about the law, lays the foundation for the Streitgespräche and legal material that follows in the Gospel. 
Matthew directs these words primarily towards his own community. Matthew 5:17-20 is a pastorally-orientated assurance to his community, who were unsettled because of accusations by Torah-abiding opponents that they were breaking the law. The issue is not about the recognition or obedience of the law, but about the understanding of the intention of God with the law. Matthew encourages his audience to continue with their style of righteousness. Jesus, their foundational Leader, defined the true meaning of the law. He spoke with ultimate authority.

Matthew poses two strongly divergent options to his readers: Either you continue with the traditional way of law observance, thereby ignoring the fulfilment of the law and the prophets, or you accept the authority of Jesus who divinely interpreted the true intention of the law.

\section{List of references}

ALLISON, D.C. 1993. The new Moses: a Matthean typology. Edinburgh: Clark.

ASCOUGH, R.S. 2001. Matthew and community formation. (In Aune, D.E., ed. The Gospel of Matthew in current study. Grand Rapids: Eerdmans. p. 96126.)

BACON, B.W. 1930. Studies in Matthew. New York: Holt.

BANKS, R. 1974a. Jesus and the law in the synoptic tradition. Cambridge: Cambridge University Press.

BANKS, R. 1974b. Matthew's understanding of the law: authenticity and interpretation in Matthew 5:17-20. Journal of biblical literature, 93:226-242.

BANKS, R.J. 1975. Jesus and the law in the synoptic tradition. Cambridge: Cambridge University Press.

BARTH, G. 1963. Matthew's understanding of the law. (In Bornkamm, G., Barth, G. \& Held, H.J., eds. Tradition and interpretation in Matthew. London: SCM. p. 59-164.)

BETZ, H.D. 1985. Essays on the Sermon on the Mount. Philadelphia: Fortress.

BETZ, H.D. 1995. The Sermon on the Mount including the sermon on the plain (Matt. 5:3-7:27 \& Luke 6:20-49). Minneapolis: Fortress.

BORNKAMM, G. 1963. End-expectations and church in Matthew. (In Bornkamm, G., Barth, G. \& Held, H.J., eds. Tradition and interpretation in Matthew. London: SCM. p. 15-51.)

BROOKS, S.H. 1987. Matthew's community, the evidence of his special sayings material. Sheffield: Journal for the Study of the Old Testament Press..

CARSON, D.A. 1982. Jesus and the Sabbath in the four Gospels. (In Carson, D.A., ed. From Sabbath to the Lord's Day. Zondervan: Grand Rapids. p. 57-97.)

CARTER, W. 1994. Household and discipleship: a study of Matthew 19-20. Sheffield: Academic Press. (Journal for the Study of the New Testament Supplement, 103.)

CHILDS, B.S. 1984. The New Testament as canon: an introduction. London: SCM. 
DAVIES, W. 1963. The setting of the Sermon on the Mount. Cambridge: Cambridge University Press.

DAVIES, W.D. \& ALLISON, D.C. 2004. Matthew 1-7. London: Clark. (International Critical Commentary, vol. 1.)

DESCAMPS, A. 1995. Essai d'interprétation de Mt 5, 17-48: Formgeschichte ou Redactionsgeschichte? Studia evangelica, 1:156-173.

DOMERIS, W.R. 1990. "Blessed are you ..." (Matthew 5:1-12). Journal of theology for Southern Africa, 73(1):67-76.

FITZMYER, J.A. 1970. The languages of Palestine in the first century AD. Catholic biblical quarterly, 32:501-531.

FLOOR, L. 1969. De nieuwe exodus: representatie en inkorporatie in het Nieuwe Testament. Potchefstroom: PU for CHE. (Th.D. thesis.)

FOSTER, P. 2004. Community, law and mission in Matthew's Gospel. Tübingen: Siebeck. (Wissenschaftliche Untersuchungen zum Neuen Testament.)

FRANCE, R.T. 1998. Matthew evangelist and teacher: New Testament profiles. Downers Grove: InterVarsity.

GUELICH, R.A. 1982. The Sermon on the Mount: a foundation for understanding. Waco: Word Books.

HAGNER, D.A. 1993. Matthew 1-13. Dallas: Word Books. (Word Biblical Commentaries, 33a.)

HILL, D. 1972. The Gospel of Matthew. London: Marshall, Morgan \& Scott.

JOHNSON, S.E. 1951. The Gospel according to St. Matthew. Nashville: Broadman \& Holman.

JOOSTEN, J. 2004. Aramaic or Hebrew behind the Greek Gospels. Analecta Bruxellensia, 9:88-102.

KÄSEMANN, E. 1969. The beginnings of Christian theology. Journal for theology and the church, 6:17-46.

KEENER, G.S. 1999. A commentary on the Gospel of Matthew. Michigan: Eerdmans.

KOOYMAN, A.C. 1992. De joodse konteks van Mattheüs 5:31-32: een bijdrage aan het debat over het gebruik van rabbijnse teksten voor de bestudering van het Nieuwe Testament. Utrecht: Rijksuniversiteit.

KÜMMEL, W.G. 1934. Jesus und der jüdische Traditionsgedanke. Zeitschrift für die neuetestamentliche Wissenschaft, 33:121-127.

LADD, G.E. 1993. A theology of the New Testament. Michigan: Eerdmans.

LLOYD-JONES, D.M. 1976. Studies in the Sermon on the Mount. Grand Rapids: Eerdmans.

LOADER, W.R.G. 1997. Jesus' attitude towards the law: a study of the Gospels. Tübingen: Siebeck (Wissenschaftliche Untersuchungen zum Neuen Testament.)

LOHMEYER, E. 1967. Das Evangelium des Matthäus. Göttingen: Vandenhoeck \& Ruprecht.

LUZ, U. 1990. Matthew 1-7: a commentary. Edinburgh: Clark.

LUZ, U. 2005. Studies in Matthew. Grand Rapids: Eerdmans.

MEIER, J.P. 1976. Law and history in Matthew's Gospel. Rome: Biblical Institute Press.

MENKEN, M.J.J. 2003. Fulfilment of Scripture as a propaganda tool in early Christianity. (In Van der Horst, P.W., Menken, M.J.J., Smit, J.F.M. \& Van Vijen, G., eds. Persuasion and discussion in early Christianity, Ancient Judaism and Hellenism. Leuven: Peeters. p. 179-198.) 
MOO, J.M. 1984. Jesus and the authority of the Mosaic law. Journal for the study of the New Testament, 20:3-49.

MORRIS, L. 1992. The Gospel according to Matthew. Michigan: Eerdmans.

MOULE, C.F.D. 1967/1968. Fulfilment words in the New Testament: use and abuse. New Testament studies, 14:293-320.

OVERMAN, J.A. 1990. Matthew's Gospel and formative Judaism: the social world of the Matthean community. Minneapolis: Fortress.

OVERMAN, J.A. 1996. Church and community in crisis: the Gospel according to Matthew. Valley Forge: Trinity.

PATTE, D. 1987. The Gospel according to Matthew: a structural commentary on Matthew's faith. Philadelphia: Fortress.

PRZYBYLSKI, B. 1980. Righteousness in Matthew and his world of thought. Cambridge: Cambridge University Press. (Monograph Series.)

RIDDERBOS, H.N. 1987. Matthew. Grand Rapids: Zondervan.

SALDARINI, A.J. 1994. Matthew's Christian-Jewish community. Chicago: Chicago University Press.

SEGAL, A.F. 1991. Matthew's Jewish voice. (In Balch, D.L., ed. Social history of the Matthean community: cross-disciplinary approaches. Minneapolis: Fortress. p. 3-37.)

SIM, D.C. 1999. The Gospel of Matthew and Christian Judaism: the history and social setting of the Matthean community. Edinburg: Clark.

STANTON, G.N. 1992. The communities of Matthew. Interpretation, 46(4):379391.

STANTON, G.N. 1993. A gospel for a new people: studies in Matthew. Edinburgh: Clark.

STOTT, R.W. 1978. The message of the Sermon on the Mount (Matthew 5-7): Christian counter culture. Illinois: InterVarsity.

STRACK, H. \& BILLERBECK, P. 1961. Kommentar zum Neuen Testament aus Talmud und Midrash. Munich: Beck.

STREETER, B.H. 1924. The four Gospels. London: Macmillan.

VAN BRUGGEN, J. 1990. Matteüs: het evangelie voor Israël. Kampen: Kok. (Commentaar op het Nieuwe Testament.)

VAN DER WALT, T. 2006. Die Messias het gekom. Potchefstroom: Potchefstroomse Teologiese Publikasies.

VILJOEN, F.P. 2006. Jesus' teaching on the Torah in the Sermon on the Mount. Neotestamentica, 40(1):135-156.

VILJOEN, F.P. 2007. The Matthean community according to the beginning of his Gospel. Acta theologica, 26(2):242-262.

VILJOEN, F.P. 2009. Die kerk en geregtigheid in die Matteus-evangelie. In die Skriflig, 43(3):649-667.

VON HARNACK, A. 1912. "Ich bin gekommen": die ausdrücklichen Selbstzeugnisse Jesu über den Zweck seiner Sendung und seines Kommes. Zeitschrift für Theologie und Kirche, 22:1-30.

\section{Key words:}

law, abrogation of the

righteousness

Sermon on the Mount

Torah 


\section{Kernbegrippe:}

Bergrede

geregtigheid

Torah

wet, verbreking van die 
